\title{
Consumer Satisfaction to Hospitality: A Case Study of Public Planning for Good Servicescapes in Taiwan
}

\author{
Chi-Shan Chen \\ National Taiwan Normal University, Taipei, Taiwan \\ Chin-Cheng Ni, Tsu-Jen Ding \\ National Hsin-chu University of Education, Hsin-chu, Taiwan
}

\begin{abstract}
The purpose of this study was to determine the influence of factors of the servicescapes designed by public planners on customer satisfaction to enable servicescapes to be used more comprehensively and to gain a general understanding. A questionnaire survey and quantitative analysis were used to evaluate the satisfaction of customers. The constructed good servicescapes in the Xinyi District that are highly satisfied by consumers include the dimensions of multi-purpose space, the pleasant modern landscape, the user-friendly environment, and the high-accessibility destination. Age, education background, and occupation of the respondents had a significant effect on the specific dimension. The result also shows that Xinyi District is more visited than other shopping areas in Taipei city. In this context, multi-purpose space of Xinyi District reduces consumer visitation, however, the pleasant modern servicescapes increase consumer visitation, meaning that it really benefits the consumers. Urban design has gained importance in the public sector agenda of many cities. In this case, well-planned landscapes with pro-development regulation, flexible negotiation, strict space restriction, and convenient transportation provided by the public sector could influence the decision-making of consumer visitation. In detail, good servicescapes exemplify the globalization of the urban form and have become an advantage of hospitality about merchandise and enjoyment for consumers. This study illustrates that the deliberative planning by the public sector could strongly meet the consumers' demand and the good servicescapes by the public sector would benefit hospitality.
\end{abstract}

Keywords: servicescapes, hospitality, public sector, consumer satisfaction

\section{Introduction}

Although urban planning has been a concern for governments, the development of hospitality has been a prominent factor of urban tourism development. The public sector also plays a multifaceted role in urban development. Button (1998) indicated that local authorities, rather than private firms, supply a large number of the goods and services available in urban areas. Similarly, the local public sector invests a considerable amount of resources in cities, especially in transportation infrastructure. Transport, as Halsall (1992) stated, is an essential part of tourist behavior, because it both facilitates recreation objectives and is a recreational activity.

Chi-Shan Chen, Ph.D. candidate, Department of Geography, National Taiwan Normal University. Email: 96924010@nccu.edu.tw.

Chin-Cheng Ni, Ph.D., professor, Department of Environmental and Cultural Resources, National Hsin-chu University of Education.

Tsu-Jen Ding, Ph.D., assistant professor, Department of Environmental and Cultural Resources, National Hsin-chu University of Education. 
Because the public sector has involved heavily in the development of tourism and hospitality, Bitner (1992) agreed with the notion that physical environments, also termed "servicescapes", play a crucial role, both positive and negative, in customers' impression formation. When consumers enter a servicescape, they sense and visualize numerous environmental cues, and unconsciously gather and retrieve these cues to create a mental picture. Numerous marketing studies have applied environmental psychology theories to examine how the physical environment affects customers. To analyze the effect of servicescape design elements, it is necessary to understand how people perceive their surroundings (Baraban \& Durocher, 2001). Servicescapes have become an increasingly prominent element affecting hospitality positioning.

The issue of servicescapes has increased the frequency of discussion of consumer satisfaction as a crucial evaluative phenomenon. Gustafsson, Johnson, and Roos (2005) defined customer satisfaction as a customer's overall evaluation of performance for a current offering. Hayes (1997) stated that knowledge on customer expectations and customer requirements is essential because: (1) It elucidates how customers define service quality; and (2) It facilitates the development or construction of suitable servicescapes. Many studies have demonstrated that customer response is influenced by individual servicescape parameters, such as color or lighting (Areni \& Kim, 1994; Crowley, 1993), as well as more abstract store characteristics, including store design and ambience (Baker, Parasuraman, Grewal, \& Voss, 2002). In a meta-study on the effect of store environmental factors on customer behavior, Turley and Milliman (2000) showed that store environmental factors exerted a profound influence on consumer appraisal and behavior. It is also believed that the application of consumer satisfaction, such as its relationship with behavior, is critical for facilitating the comprehension of this phenomenon.

Currently, few studies have shown which environmental measures could be adopted by urban planners to benefit the hospitality sector. In this study, Xinyi District, a famous planned area in Taipei city, Taiwan, is discussed by examining: (1) The involvement of the public sector in the formation of the servicescapes as a good hospitality attraction in Xinyi District; (2) How is the consumer satisfaction with the good public-supplied servicescapes? (3) Does the personal background influence consumer perception or satisfaction? and (4) Whether good servicescapes attract more consumer visits or benefit the hospitality industry? The following sections detail this critical concept.

\section{Literature Review}

\section{Public Sector in Action}

The public sector comprises multiple levels of government and may become involved in tourism for various economic, political, social, and environmental reasons (Hall \& Jenkins, 1998). In a discussion on the role of the state in tourism, Hall (2000) identified the following seven areas of public sector involvement: (1) coordination; (2) planning; (3) legislation and regulation; (4) government as an entrepreneur; (5) stimulation; (6) social tourism; and (7) public interest protection. Although numerous public sector actions affect urban form, the following four factors are particularly crucial: (1) transportation; (2) public utilities; (3) urban services; and (4) direct control over land use. The majority of public investment categories shape the city land use pattern and every parcel of land within a city (Richardson, 1977).

From a policy perspective, public sector spatial planning has become increasingly ambitious and active with regard to creating conditions for economic growth, even if the consequences of such actions have been spatial disparity and uneven development (Hudson, 2001). As the drastic industry transformation, a city that is 
planned by the public sector today is developed to be "a consumer city"; such planning is based heavily on consumption and economic growth. Miles (2010) stated that cities worldwide have been branded as places to consume, destinations and centers for cultural consumption, and places to be consumed in.

In most cases, urban development projects were followed by general controlled rules from the local government. But in other cases, they could be initiated by means of "exceptionality" measures, such as the freezing of conventional planning tools, bypassing statuary regulations and institutional bodies, the creation of project agencies with special or exceptional powers of intervention and decision-making, and/or a change in national or regional regulations (Swyngedouw, Moulaert, \& Rodriguez, 2002). The measures usually could construct unique urban images for the specific purposes. While economic processes were rapidly globalizing and cities were trying to carve out their niche within the new consumption transformation. During the past couple of decades, urban design has gained importance in the public sector agenda of many cities. Especially, architecture exemplifies the globalization of the urban form: "It is certainly the search for architectural icons that drives the process in globalizing cities" (Sklair, 2005, p. 498). In a world of abundant attractions, the best architectural designs are considered prerequisite for the production of instantly recognizable distinctiveness, since "projecting the "image of being global' is as important as 'being global' in the competitive global economy" (Marshall, 2003, p. 23). Regional transformations in economic policy and in ways in which policy is delivered and implemented also account for explanation of being a global city. From land use regulation to transportation route upgrades, opportunities to mobilize local assets into viable economic contributors depend on a supportive policy and investment climate (Markey, Halseth, \& Manson, 2008). The planning apparatus has become increasingly business- and market-oriented (Brenner, 2000).

\section{Interaction With the Servicescapes}

Servicescape is a term coined by Bitner (1992) to address the role of manmade physical surroundings in consumption settings. It denotes a physical, material setting designed and built to influence consumer behavior. The physical and social aspects of hospitality servicescapes could have an independent and holistic influence on the quality of consumers' image perceptions. Bitner (1992) suggested that consumer recognition and interpretive signs, symbols, and artefacts are particularly important in forming their first impressions in servicescapes. She also postulated that personality traits, conceptualized as arousal-seeking tendencies and an ability to screen environmental stimuli, moderate the relationship between a perceived servicescape and behavior. Siddiqui and Tripathi (2011) further stated that servicescapes comprise the following four dimensions: (1) general interior; (2) social dimension; (3) internal display facilities; and (4) exterior facilities.

Modifications to the internal and external physical features of hospitality environments can affect consumer perceptions (Kimes \& Robson, 2004). Empirical studies have shown that customers respond both cognitively and emotionally to the physical environment (Lin, 2004; Kim \& Moon, 2009). Furthermore, many studies on servicescapes have also presented evidence that the physical service environment (also known as servicescapes) that customers experience has a critical role in customers' emotional responses (i.e., appeal and pleasure). Thus, developing servicescapes enhances or inhibits customer satisfaction, and eventually leads to either approach or avoidance behavior (Bitner, 1992; Turley \& Milliman, 2000).

In hospitality settings, environmental, social, and ambient cues can influence customer perceptions (Spielmann, Laroche, \& Borges, 2012). The semiotic qualities of hospitality spaces can shape the actions and perceptions of the hosts and guests, or those of the service providers and their consumers (Lugosi, 2003; 
Cuthill, 2007; Di Domenico \& Lynch, 2007). In addition, Mitchell, Kahn, and Knasko (1995) considered the service environment or servicescape as a composition of aesthetic design, functional design, and social elements. Ambient or aesthetic design elements are intangible background conditions that tend to affect the senses and in some cases may have a relatively subconscious effect on the customer. The relationship between a service environment and consumer experience has long been recognized (Pullman \& Gross, 2004). Seiders, Voss, Grewal, and Godfrey (2005) indicated that store environments could affect the behaviors of shoppers through their emotional and cognitive responses, as well as their physiological state, without the shopper's conscious awareness. Accordingly, Berry and Bendapudi (2003) recommended that operators could purposefully design and manipulate their service environments to influence the perceptions and experiences of customers. Within the case study site, servicescape is defined as the physical environment of an organization and encompasses various elements, such as design and decoration. The physical environment undoubtedly has a critical role; however, the furnishings and layout of the environment have been considered.

Previous studies have shown that human behavior is the result of environmental factors (Schiffman, 2001). When consumers are engaged in a servicescape, they construct experiences that fit with their life themes, and they project and connect these experiences to culturally embedded rituals and meanings (Schmitt, 2003). Particularly in the hospitality industry, consumers tend to interact with the physical environment more than they interact with service agents; people generally receive various stimuli from servicescapes, cognitively organize them into groups, and then form images as a whole (Lin, 2004). A highly planned environment provided by the public sector should influence the decisions made by consumers and guide their inferences about merchandise, service quality, and enjoyment at the stores.

\section{Importance of Consumer Satisfaction}

Recently, numerous researchers have expressed their concern about consumers' aesthetic experience (Joy \& Sherry, 2003), authenticity (Rose \& Wood, 2005), emotional responses (Ramanathan \& Williams, 2007), excitement (Ding, Eliashberg, Huber, \& Saini, 2005), hedonic experience (Nelson \& Meyvis, 2008), prestige and status (Ivanic \& Nunes, 2009), processing fluency (Allen, 2002), retail experience (Verhoef, Lemon, Parasuraman, Roggeveen, Tsiros, \& Schlesinger, 2009), and visceral experience (Chang \& Pham, 2009). As the physical environment can influence behavior and create a mental image, servicescapes are particularly critical for service businesses such as hotels and restaurants (Baker, 1987; Bitner, 1986). Furthermore, because services are a consumption experience, the servicescape is thought to be highly influential in communicating a firm's image and purpose to its customers, thereby affecting customer satisfaction. In the context of leisure activities, Bitner (1992) and Wakefield and Blodgett (1999) indicated that the servicescape has a substantial effect on customer satisfaction.

In a comprehensive study, Kotler (2000) defined consumer satisfaction as a person's feelings of pleasure, excitement, delight, or disappointment resulting from comparing a products' perceived performance to his or her original expectations. A review of extant literature and empirical evidence has indicated that customers are gradually replacing business operators in determining the market orientation. Gustafsson et al. (2005) defined customer satisfaction as a customer's overall evaluation of performance for a current offering. Consequently, studying the satisfaction of consumers may assist researchers in elucidating the factors that affect consumer demand, thereby facilitating greater profits. Because the concept of consumer satisfaction is central to consumer behavior, it is critical to emphasize the relationship between consumer satisfaction and consumer behavior. 
In this competitive market environment, the success of hospitality services depends strongly on a thorough analysis of customer satisfaction. Customer satisfaction is one of the most important and most frequently examined concepts of modern marketing thought and practice, because it plays an important role in the survival and future of tourism products and services (Gursoy, McCleary, \& Lepsito, 2003; 2007). It also significantly influences the choice of destination, the consumption of products and services, and the decision to return (Kozak \& Rimmington, 2000).

Jasimin (2011) argued that a person's level of satisfaction varies according to temporal, situational, and environmental factors. Wakefield and Blodgett (1994, p. 68) asserted, "The longer one spends in a facility, the greater the likelihood that the perceived quality of the servicescape will play an important role in determining satisfaction with the service". Marketers generally conceive of consumer perceptions, especially satisfaction, as having a direct influence on their behaviors; thus, servicescapes might also affect their ultimate satisfaction with a service. This discussion shows that the importance of satisfaction as a construct of central interest to marketers is well established. In this study, we base the servicescape framework on specific aspects of Bitner's (1992) servicescape framework, and reference the model proposed by Wakefield and Blodgett (1996) to study the effect of servicescapes on customer perception in hospitality service settings.

\section{Research Methodology}

\section{Inductive Analysis on Servicescapes Planned by the Public Sector}

In Xinyi District, why this district presented the unique images by the public sector? How it became the exceptionality measures by the public sector? What is the good design of servicescapes by the public sector? There is the orientation for the study. We tried to analyze the following dimensions of the zoning of land uses, the control of urban features, the demand of pedestrians or users, and the transportation of external connections, and to provide the elements or variables for consumer perception.

According to Bitner (1990), dimensions like signs artifacts, etc. are very important in formulating internal customer and employee responses which can be categorized into cognitive, emotional, and psychological responses. These internal responses finally lead to overt behavioral responses towards the environment. Hopkins, Raymond, and Grove (2003), Williams and Dargel (2004), and many others consider that aesthetics, professionalism, and various design element details can prim attitude and behavior. With a proper design of a servicescape, the arousal and other positive or negative affective reactions can be controlled to a fairly favorable degree. To understand consumer satisfaction with public sector-planned servicescapes, this qualitative study analyzed the multifaceted context of Xinyi District to identify which servicescape characteristics facilitate consumer demand.

\section{Questionnaire Design and Data Collection Procedure}

The population consists of the people who visit Xinyi District for shopping, seeing movies, having meals, or acting leisure, etc.. A random sampling questionnaire survey was conducted near the exit of the municipal rapid transit (MRT) station, department stores (Shin Kong Mitsukoshi), and cinemas (Vie Show Cinemas) on weekdays and weekends afternoon and evening from April to June in 2009. A total of 493 people above teenager successfully completed the questionnaire. In this quantitative study, we employed a questionnaire to collect information on consumer satisfaction. The questionnaire comprised three sections. The first two sections were designed to obtain data on consumers' personal backgrounds, and how their behavior in Xinyi District 
differed from their behavior in other business areas. The third section contained 12 items oriented based on the aforementioned qualitative analysis measuring the consumer satisfaction with the Xinyi District environmental settings that had been influenced by urban planning. A 6-point Likert scale was employed for all of the measurements $(1=$ strong dissatisfaction, $6=$ strong satisfaction $)$.

Among the respondents, $212(43.0 \%)$ were men and 281 (57.0\%) were women, 380 (77.1\%) reported being single, and $323(65.5 \%)$ were older than 26 . A majority of the respondents $(77.5 \%)$ had a university degree or higher. Approximately $24.9 \%$ of the respondents worked in service industries, and $43.8 \%$ reported an average monthly income ranging from US $\$ 1,000$ to US $\$ 1,666$.

\section{Discourse on Good Servicescapes of the Xinyi District Planning}

\section{Conceived Servicescapes Based on Normative Rules}

Xinyi District, which covers an area of approximately $1.53 \mathrm{~km}^{2}$, is located at the eastern part of Taipei city. In 1977, Xinyi District was originally conceived as a residential and local commercial center. A substantial change in 1995, the Asia-Pacific Finance Center project entitled "Taipei's Manhattan", exuberated (Chen, Tseng, \& Chan, 2001). However, urban planning is implemented in Xinyi District in two main ways: urban plan control and design review. The changes of the planning context are based on The Research of Urban Design in Xinyi Planning District proposed by Kaku Morin Group (KMG) Association in 1980, and then, the process is through the original urban plan, the first overall review, the second overall review, and the third planning adjustment. At the same time, the real space of Xinyi Sub-Center also changed gradually in this process. The construction, regardless of its physical form or cultural representation, is highly intertwined with processes associated with globalization and the evolution of local institutional contexts and urban form (Jou \& Lin, 2008). It deserves to be mentioned that the control of urban features is the first case in Taiwan. There were more than 20 individual rules and unique land use regulations in the Xinyi District. The four findings that had the greatest influence on the servicescapes are analyzed as follows.

Pro-development regulation and intensity for multiple uses of land. To cooperate with the objective from "local center" to "international financial center", the regulations governing land use changed from mixed residential-commercial to commercial only. The central types of business included branches of financial institutions, recreational and tourist facilities, and hotels. The public sector modified the legal coverage rate and plot ratio, thereby creating a broad ground environment; moreover, the urban planners preserved considerable public space for parks and an art auditorium (Taipei City Government, 2001); it was not until after 1997 that new hotels, restaurants, movie theaters, art centers, and trade exhibition rooms emerged.

Flexible negotiation of building height and control of open space for modern city images. The government issued specific modifications for buildings constructed in this district. In 2004, Taipei 101 became the world's tallest building (508 m, 101 floors); although the constructors initially planned it to be a 66-floor building, they also considered designing the building to be 88, 99, or 100 floors (Hsu \& Lin, 2008). The flexible negotiation of height facilitated the first opportunity to establish a city landmark by constructing a tall building to create a diverse city landscape. Taipei 101 has been a key attraction in Taipei city, for both commercial and tourism purposes. In addition, from a functionalist perspective on urban planning, new buildings would have considerable amounts of sunshine, airflow, and outdoor space (Chen et al., 2001). The broad look of landscape is full of this district. 
Strict space restrictions on urban functions. The planners designed Xinyi District to be a grid system of interleaved roads and pedestrian paths. The sidewalks flank the roads so that the commercial buildings face the roads on one side and the pedestrian paths are on the other side (Lin, Hsiao, \& Chung, 2006). The buildings are spaced by a large gap. The base of the walls could not be higher than $45 \mathrm{~cm}$, and safety regulations prevented designers from setting commercial items on the buildings (Taipei City Government, 2001). In addition to pedestrian and vehicle separation, pedestrian protection facilitated the construction of a user-friendly environment.

Convenient transportation for urban-rural connection. In addition to the land use, the MRT stations have serviced Xinyi District since 1999. There are two MRT lines (East-West and North-South) that provide convenient accessibility from all areas of the Greater Taipei metropolitan area. In 2013, a third MRT line opened that passes through this district. There are also numerous bus routes connecting Taipei city with the surrounding rural areas. Consequently, in 2010, the public sector established a new transfer terminal based on the build-operate-transfer model (President International Development Corporation, 2012). Moreover, a substantial number of arterial roads and freeways lead to this area.

To examine the outcome of urban planning in Xinyi District, we extracted and incorporated specific characteristics relevant to consumers based on the contents of the discussed zoning regulations, such as: (1) appearance of height and open space control; (2) friendliness of urban design; and (3) public transportation quality. The extracted characteristics of servicescapes comprised the following four dimensions for the consumer satisfaction test: (1) multi-purpose space; (2) pleasant modern landscape; (3) user-friendly environment; and (4) highly accessible destination.

\section{Comparison With Other Shopping Areas in Taipei}

According to various elements such as the geographic environment, consumption patterns, social conditions, and economic background, Xinyi District belongs to a type of public sector development discussed by $\mathrm{Li}$ (2003). This type of shopping area is policy-oriented. Simultaneously, Xinyi District was planned as a sub-metropolis core that was originally intended to relieve the crowdedness in Western Taipei. The development process was dominant by social, economic, and political factors relevant to this area; few shopping areas (e.g., Dazhi) were similar to Xinyi District.

According to Li (2003), another type of development in the historical context usually forms in a natural process; this classification is representative of the majority of other shopping areas in Taipei. Fragmented commercial centers emerged during the 1930s, each associated with different historical factors, such as old regional business centers (e.g., Ximen, Nanjing West Road, Zhongxiao, Tien-mu, and Shilin), transport ports (e.g., Taipei Main Station), and school-pattern commercial districts (e.g., Guangang).

\section{Consumer Satisfaction Analysis}

In this study, we employed confirmatory factor analysis (CFA) to analyze consumer satisfaction after assessing the fit of the full measurement model by applying maximum likelihood estimation. According to the guidelines provided by Kline (2005) and Arbuckle (2007), the measurement model demonstrates a good fit to the data and is thus acceptable. The relative chi-square $\left(\chi^{2} / d f=4.23\right)$ shows a reasonable fit to the sample data $(N=493)$. The root mean square error of approximation $(\mathrm{RMSEA}=0.08)$ also indicates a reasonable fit. The values for the comparative fix index $(\mathrm{CFI}=0.96)$ and goodness-of-fit $(\mathrm{GFI}=0.94)$ indicate that the data are a good to fair fit for the model. Table 1 shows the CFA results, as well as the descriptive statistics for the scales 
and individual items. For the measurement model employed in this study, the standardized parameter coefficients (loadings) are significant for all of the latent constructs for their corresponding indicators $(t>1.96)$. All of the latent constructs demonstrate high internal consistency $(\alpha>0.70)$.

The descriptive statistics revealed that all the levels of the perception were over the average $(M=3.5)$. This implies that the consumers were satisfied with the urban planning. Among the four dimensions, high-accessibility destination $(M=4.90)$ ranked the highest because of the convenience provided by the MRT and bus systems. The pleasant modern landscape dimension ranked the second $(M=4.68)$, implying that the consumers were aware of the discussed urban design controls. In addition, a survey of three shopping areas which the respondents visited most frequently (multiple choices were permitted) showed that Xinyi District (46.2\%) was more popular than the Zhongxiao area (current CBD, 45.4\%) and the Ximen area (decayed CBD, $34.9 \%$ ) with the accumulative values. Data can be seen in Table 1.

Table 1

Measurement of CFA for Four Dimensions by 12 Items

\begin{tabular}{|c|c|c|c|c|c|}
\hline Component & $\mathrm{M}$ & SD & Loading & $t$ & $\alpha$ \\
\hline Multi-purpose space & 4.08 & & & & 0.78 \\
\hline I like the diversity of merchandises & 4.10 & 1.129 & 0.69 & 15.32 & \\
\hline I like the leasing-bike service & 4.17 & 1.131 & 0.73 & 16.46 & \\
\hline I like the plentiful exhibitions & 3.98 & 1.160 & 0.76 & 17.19 & \\
\hline Pleasant modern landscape & 4.68 & & & & 0.70 \\
\hline I like the no irregular signboards & 4.57 & 1.075 & 0.57 & 12.62 & \\
\hline I like the sufficient public open space & 4.66 & 0.931 & 0.69 & 15.85 & \\
\hline I like the stores with big area & 4.82 & 0.886 & 0.71 & 16.34 & \\
\hline User-friendly environment & 4.62 & & & & 0.79 \\
\hline I like the wide sidewalks & 4.90 & 0.827 & 0.71 & 13.53 & \\
\hline I like the pedestrian and vehicle separated & 4.66 & 0.911 & 0.81 & 19.84 & \\
\hline I like the green land planned & 4.30 & 1.022 & 0.72 & 16.54 & \\
\hline High-accessibility destination & 4.90 & & & & 0.81 \\
\hline I like the direct MRT accessibility & 5.13 & 0.912 & 0.80 & 19.67 & \\
\hline I like the direct bus lines & 4.91 & 0.978 & 0.86 & 21.49 & \\
\hline I like the convenience of driving routes & 4.67 & 1.155 & 0.63 & 14.50 & \\
\hline
\end{tabular}

For the one-way analysis of variance (ANOVA), the independent variables were age, education background, occupation, monthly income, and visit frequency, and the dependent variable was the consumer perception or satisfaction of the four dimensions (multi-purpose space, pleasant modern landscape, user-friendly environment, and highly accessible destination). Table 2 shows the satisfaction results for the four dimensions. One of the major results from the analysis was that age and education background had a significant effect on the multi-purpose space dimension. The post hoc tests of multiple comparisons indicated that the respondents older than 46 well perceived the place of multiple functions than the people aged 25-35 $(p=0.068)$. Furthermore, the respondents whose highest level of education was senior high school expressed a greater preference for the diverse provision than did the respondents who had graduated from a university $(p=0.075)$. The occupation of the respondents had a significant effect on the user-friendly environment dimension. The post hoc tests showed that the respondents who were employed in high-technology industries expressed greater satisfaction with the walking environment than the respondents who worked as freelancers $(p=0.023)$. The visit frequency also had a 
statistically significant relationship with the dimensions of pleasant modern landscape and high-accessibility destination. Compared to the respondents who visited Xinyi District once or twice per year, the post hoc test results show that the respondents who visited the area more than once per week were highly satisfied with both pleasant modern landscape $(p=0.026)$ and high-accessibility destination $(p=0.042)$.

Table 2

ANOVA for Satisfaction of Four Dimensions

\begin{tabular}{|c|c|c|c|c|c|}
\hline Variable & Statistic & Multi-purpose space & $\begin{array}{l}\text { Pleasant modern } \\
\text { landscape }\end{array}$ & $\begin{array}{l}\text { User-friendly } \\
\text { environment }\end{array}$ & $\begin{array}{l}\text { High-accessibility } \\
\text { destination }\end{array}$ \\
\hline \multirow{3}{*}{ Sex } & $d f$ & 1 & 1 & 1 & 1 \\
\hline & $F$ & 1.289 & 0.012 & 2.512 & 0.781 \\
\hline & Turkey's HSD & & & & \\
\hline \multirow{3}{*}{ Age } & $d f$ & 3 & 3 & 3 & 3 \\
\hline & $F$ & $2.777^{* *}$ & 0.128 & 0.586 & 0.547 \\
\hline & Turkey's HSD & $\begin{array}{l}26-35<45 \uparrow^{*} \\
36-45<45 \uparrow^{*} \\
\end{array}$ & & & \\
\hline \multirow{3}{*}{ Education } & $d f$ & 2 & 2 & 2 & 2 \\
\hline & $F$ & $2.398^{*}$ & 0.073 & 0.523 & 0.295 \\
\hline & Turkey's HSD & $\begin{array}{l}\text { Senior } \downarrow> \\
\text { graduated } \uparrow^{*}\end{array}$ & & & \\
\hline \multirow{3}{*}{ Income } & $d f$ & 3 & 3 & 3 & 3 \\
\hline & $F$ & 0.704 & 1.043 & 0.569 & 0.075 \\
\hline & Turkey's HSD & & & & \\
\hline \multirow{3}{*}{ Occupation } & $d f$ & 4 & 4 & 4 & 4 \\
\hline & $F$ & 0.394 & 0.321 & $2.364^{*}$ & 0.785 \\
\hline & Turkey's HSD & & & $\begin{array}{l}\text { Hi-tech > freelancer, } \\
\text { etc. }\end{array}$ & \\
\hline
\end{tabular}

Note. ${ }^{*}: p<0.1 ;{ }^{* * *}: p<0.05$.

\section{Results and Discussion}

\section{Individual Attributes and Consumer Satisfaction}

In this study, we evaluated whether certain dimensions for servicescapes planned by the public sector affected consumer satisfaction. Overall, the results show that after controlling for better external service display, consumers reported greater satisfaction when they shop in an aesthetically pleasing physical environment. Their level of satisfaction also affected their intention to revisit that shopping area. Similar to the dynamics of satisfaction discussed by Mittal, Kumar, and Tsiros (1999), the importance of personal factors determining the overall consumer satisfaction is subject to change over time. The final section identifies and discusses four crucial implications.

Age

Compared to the respondents aged $26-34$ or $35-44$, the consumers who were older than 45 were clearly more satisfied with the multi-purpose space and user-friendly environment. This implies that older adult consumers tended to shop in one location if it meets all their needs. In Taiwan, because of the conventional habits to shop in a high-density commercial district, older adult consumers are accustomed to shopping in one location, and the proximity reduces transport costs and saves energy; furthermore, they are typically unfamiliar with elaborate and dispersive information acceptation. Consequently, the consumers who were older than 45 are highly aware of the benefits of urban planning, which supports the findings of Tsai (2009). 


\section{Education Background}

Regarding the multi-purpose space, the respondents whose highest level of education was senior high school reported greater satisfaction than the respondents who graduated from a university. The results imply that consumers with a lower level of education experience a higher level of satisfaction. They are easily convinced of the benefits provided by public sector planning and mega-enterprise promotions, although they lack professional knowledge on servicescapes. In addition, this consumer group enjoyed a diverse shopping experience in one location.

\section{Occupation}

Regarding the user-friendly environment, the respondents who worked in high-technology industries were more satisfied than the respondents who worked as freelancers. In the context of this research, people employed in high-technology industries are accustomed to specific roles associated with the division of labor, and they tend to work in a well-organized environment; thus, the urban design could be a highly suitable match for their demands. In contrast to the freelancers, they frequently obtain new information and work in a flexible, individual space, which could explain the difference in preference between the two groups.

\section{Consumer Satisfaction With the Servicesacpes and in Relation to the Visitation}

Based on the survey finding that Xinyi District (46.2\%) was more popular than the other two main shopping areas, the research intends to inquiry whether consumer visitation in Xinyi District will be affected by the four dimensions of satisfaction (multi-purpose space, pleasant modern landscape, user-friendly environment, and high-accessibility destination) or not. Logistic regression analysis was employed in this part (see Table 3).

Table 3

Logistic Regression on the Characteristic of Consumer Visitation in Xinyi District

\begin{tabular}{llll}
\hline Dimension & $b$ & s.e. & Sig. \\
\hline Constant & -1.586 & 0.731 & 0.030 \\
Multi-purpose space & -0.075 & 0.038 & 0.051 \\
Pleasant modern landscape & 0.103 & 0.055 & 0.059 \\
User-friendly environment & 0.045 & 0.051 & 0.380 \\
High-accessibility destination & 0.020 & 0.045 & 0.661 \\
\hline
\end{tabular}

Note. Log-likelihood $=670.894 ; d f=4 ; N=493$.

In our finding, the data of multi-purpose space satisfaction $(p=0.051)$ indicate that it strongly obstructs consumer visiting phenomenon. Although Xinyi District provides various choices of merchandise, the high land price and rent make it a high consumption area (Taipei Times, 2013a) affecting consumer visitation. Besides, with the maturity of public planned Youbike system, there are many consumers or visitors renting bikes here (Liberty Times, 2013). Nevertheless, some bikers have stopped riding on the streets and started riding their bikes on wide sidewalks, and this situation may have angered or frightened many consumers (VOA News, 2014), thus decreasing the visiting desire of the respondents. Furthermore, lots of exhibitions would be held in Taipei World Trade Center in this district which regularly draws large crowds of visitors (Taipei Times, 2013b), causing traffic jam or overcrowded condition and reducing the quality of servicescape. All things considered, multi-purpose space may cause disorder and is not likely to create higher consumer visitation. 
The findings also show that pleasant modern landscapes, like no irregular signboards, stores with big area, and sufficient public open space, have a positive effect on consumer visitation in real situation $(p=0.059)$. The result indicates that consumers are satisfied with orderly signboards that facilitate them to collect space information with smaller visual pressure, and to have snug consuming experience. Moreover, wide floor space is beneficial to move across stores and also to reduce mutual interference between consumers that led to higher consumer visitation lastly. For these reasons, pleasant modern landscapes with the merits of good spatial order and wide space have a positive effect on consumer visitation. The result also corresponds to the idea proposed by Mitchell et al. (1995) that consumers are satisfied with aesthetic, unique servicescapes, and also with wide open public space.

\section{Conclusion}

The origin of urban planning is primarily associated with physical and spatial planning (Rakodi, 1997). It has its roots in architecture and engineering and was primarily concerned with the "orderly, aesthetic, and healthy layout of buildings and land uses" (Devas \& Rakodi, 1993, p. 41). Today, scholars in the field of public urban planning are calling for a wider conception of planning and a shift of focus towards recognition of politics, power, and governance (Rakodi, 2001). The hospitality industry comprises various sectors operating worldwide. Each servicescape in each sector is subtly different to the consumers, who have distinct characteristics. Developing the notion purported by Bitner (1992) that servicescapes produce a substantial influence on customer satisfaction, the paper successfully presented the notion of servicescapes to conceptualize the experiences that emerge in public-sector-planned moments.

Commercial operators could provide a context for functional hospitality transactions and the creation of hospitable relationships; however, the public sector could also have a critical role in facilitating and organizing consumers' experiences. This result corresponds with the offer of hospitality by the public sector being a means of achieving social or political goals (Lugosi, 2008). In this context, it became important to rethink the servicescapes provided by public sector in order to increase their quality, thereby satisfying the public's needs and, as far as possible, trying to please people and companies, favouring good governance and national economic competitiveness. The original idea of residential use transformed to the business center, and finally the main center became the international financial center where headquarters are aggregated (Yang, 2009). Another feature related to this global integration process has been the development of central business districts (CBDs) with office and hotel buildings, shopping complexes, etc.. As global cities have appeared in various places around the world, the need for creation of landmark buildings and world-city skylines has grown. Tall, designed buildings (i.e., Taipei 101 and other high buildings) have played major roles in giving instant identity and prestige to new districts that seek to compete successfully in the global economy. Skyscrapers and high-rise buildings are conspicuous landmarks in the urban form of global cities, and their physical form or modern cityscapes highly intertwined with processes of globalization and contexts of urban planning. In terms of objectives, planning was no more dedicated to solving urban problems, but as a way to created premium hospitality settings, and was the most-visited area among the nine shopping areas in Taipei city. Xinyi District was planned to strong satisfaction and the comparatively higher visitation rate shows that consumers' demands are obviously met through public sector-planned servicescapes. Therefore, good servicescapes could be viewed as a helpful means for applying public sector planning to stimulate regional development and affect the satisfaction and behavior of a crowd. 
Servicescapes are complex and have many design elements, and the physical service environment plays an important role in shaping the service experience and delivering customer satisfaction. Based on the aforementioned quantitative analysis measuring the consumer satisfaction with the Xinyi District environmental settings, there are four dimensions that had been influenced by urban planning: multi-purpose space, pleasant modern landscape, user-friendly environment, and high-accessibility destination. Under the four dimensions, the high rankings of satisfaction are high-accessibility destination and pleasant modern landscape; the low satisfaction shows on the multi-purpose space. Individual attributes would work upon consumer satisfaction with servicescapes. The findings pointed that the respondents who were older than 45 and those whose education was lower than senior high school reported greater satisfaction. Besides, the ones who worked in a high-technology industry presented better perception on the dimension of user-friendly environment with the urban planning at Xinyi District.

One of the results shows the close relationship between the four dimensions of consumer satisfaction and the consumer visitation in Xinyi District. Especially under the fact that Xinyi District was more popular than other areas, according to the result of logistic regression analysis, pleasant modern landscape has a positive effect on consumer satisfaction in relation to the visitation because of that orderly and wide, open servicescapes benefit to move across stores, and also to reduce mutual interference in consumer action. On the other hand, multi-purpose space may lead to traffic problem or overcrowded condition, thus reducing the quality of servicescape. Consequently, it would decrease consumer visitation. In short, the findings indicate that combining with the idea of global city design, well-planned modern servicescapes by public sector upgrade the consumer satisfaction, especially in high accessibility. Practically, in order to create a high visiting environment, apart from providing convenient transport infrastructure, public sector could meet this purpose by means of urban planning to shape a wide, aesthetic servicescapes with sufficient public open space for consumers. This kind of good servicescape would really benefit the hospitality development.

\section{References}

Allen, D. E. (2002). Toward a theory of consumer choice as sociohistorically shaped practical experience: The fits-like-a-glove (FLAG) framework. Journal of Consumer Research, 28(4), 515-532.

Arbuckle, J. L. (2007). Amos 16.0 user's guide. Chicago: SPSS Inc..

Areni, C. S., \& Kim, D. (1994). The influence of background music on shopping behavior: Classical versus top-forty music in a wine store. In L. McAlister, \& M. L. Rothschild (Eds.), Advances in consumer research (Vol. 20, pp. 336-440). Provo, UT: Association for Consumer Research.

Baker, J. (1987). The role of the environment in marketing services: The consumer perspective. In A. C. John, A. C. Carole, \& S. James (Eds.), The services challenge: Integrating for competitive advantage (pp. 79-84). Chicago: American Marketing Association.

Baker, J., Parasuraman, A., Grewal, D., \& Voss, G. B. (2002). The influence of multiple store environment cues on perceived merchandise value and patronage intentions. Journal of Marketing, 66(2), 120-141.

Baraban, R. S., \& Durocher, J. F. (2001). Successful restaurant design (2nd ed.). New York, NY: John Wiley \& Sons.

Berry, L. L., \& Bendapudi, N. (2003). Clueing in the customers. Harvard Business Review, 81(2), 100-106.

Bitner, M. J. (1986). Consumer responses to the physical environment in service settings. In M. Venkatesan, D. Schmalensee, \& C. Marshall (Eds.), Creativity in services marketing: What's new, what works, what's developing (pp. 89-93). Chicago: American Marketing Association.

Bitner, M. J. (1990). Evaluating service encounters: The effects of physical surroundings and employee responses. Journal of Marketing, 54(2), 69-82.

Bitner, M. J. (1992). Servicescapes: The impact of physical surroundings on customers and employees. Journal of Marketing, $56(2), 57-71$. 
Brenner, N. (2000). Building "Euro-regions": Locational politics and the political geography of neoliberalism in post-unification Germany. European Urban and Regional Studies, 7(4), 319-345.

Button, K. J. (1998). Infrastructure investment, endogenous growth, and economic convergence. Annals of Regional Science, $32(1), 145-162$.

Chang, H. H., \& Pham, M. T. (2009). Differential reliance on feelings in the present vs. the future (or past): Affect as a decision making system of the present. Working Paper, Columbia University.

Chen, W. S., Tseng, S. C., \& Chan, S. C. (2001). Above Taipei. Taipei, Taiwan: Yuan-Liou Press.

Crowley, A. E. (1993). The two-dimensional impact of color on shopping. Marketing Letters, 4(1), 59-69.

Cuthill, V. (2007). Sensing and performing hospitalities and socialities of tourist places: Eating and drinking out in Harrogate and Whitehaven. In J. G. Molz, \& S. Gibson (Eds.), Mobilizing hospitality: The ethics of social relations in a mobile world (pp. 83-100). Aldershot: Ashgate.

Devas, N., \& Rakodi, C. (1993). Planning and managing urban development. In N. Devas, \& C. Rakodi (Eds.), Managing fast growing cities: New approaches to urban planning and management in the developing world. New York, NY: Longman Scientific and Technical.

Di Domenico, M., \& Lynch, P. (2007). Commercial home enterprises: Identity, home, and setting. In C. Lashley, P. Lynch, \& A. J. Morrison (Eds.), Hospitality: A social lens (pp. 117-128). Oxford: Elsevier.

Ding, M., Eliashberg, J., Huber, J., \& Saini, R. (2005). Emotional bidders-An analytical and experimental examination of consumers' behavior in a Priceline-like reverse auction. Management Science, 51(3), 352-364.

Gursoy, D., McCleary, K. W., \& Lepsito, L. R. (2003). Segmenting dissatisfied restaurant customers based on their complaining response styles. Journal of Foodservice Business Research, 6(1), 25-44.

Gursoy, D., McCleary, K. W., \& Lepsito, L. R. (2007). Propensity to complain: Effects of personality and behavioral factors. Journal of Hospitality and Tourism Research, 31(3), 358-386.

Gustafsson, A., Johnson, M. D., \& Roos, I. (2005). The effects of customer satisfaction, relationship commitment dimensions, and triggers on customer retention. Journal of Marketing, 69(4), 210-218.

Hall, C. M. (2000). Tourism planning: Policies, processes, and relationships. Essex: Prentice Hall.

Hall, C. M., \& Jenkins, J. M. (1998). The policy dimensions of rural tourism and recreation. In R. Butler, C. M. Hall, \& J. Jenkins (Eds.), Tourism and recreation in rural areas (pp. 19-42). Chichester: John Wiley \& Sons.

Halsall, D. (1992). Transport for tourism and recreation. In B. S. Hoyle, \& R. D. Knowles (Eds.), Modern transport geography (pp. 155-177). London: Belhaven.

Hayes, B. E. (1997). Measuring customer satisfaction: Survey design, use, and statistical analysis methods (2nd ed.). Milwaukee, Wisconsin: ASQ Quality Press.

Hopkins, C. D., Raymond, M. A., \& Grove, S. J. (2003). Designing the E-servicescape: Data-driven observations. Paper presented at the American Marketing Association Frontiers in Services Conference, College Park, MD, University of Maryland.

Hsu, K. H., \& Lin, H. M. (2008). Standing on the top of Taipei 101. Retrieved from http:/hk.huaxia.com/tslj/rdrw/2008/09/1175848.html

Hudson, R. (2001). Producing places. New York, NY: Guilford Press.

Ivanic, A. S., \& Nunes, J. C. (2009). The intrinsic benefits of status: The effects of evoking rank. Working Paper, University of Southern California.

Jasimin, T. H. (2011). Tenants' preferences on facilities and design of apartment (Masters thesis, Faculty of Geoinformation and Real Estate, Universiti Teknologi Malaysia).

Jou, S. C., \& Lin, J. H. (2008). Racing for the sky: The local context of high-rise building construction in Taipei. Journal of City and Planning, 35(1), 1-28.

Joy, A., \& Sherry, J. F. (2003). Speaking of art as embodied imagination: A Multisensory approach to understanding aesthetic experience. Journal of Consumer Research, 30(2), 259-282.

Kim, W. G., \& Moon, Y. J. (2009). Customers' cognitive, emotional, and actionable response to the servicescape: A test of the moderating effect of the restaurant type. International Journal of Hospitality Management, 28(1), 144-156.

Kimes, S. E., \& Robson, S. K. A. (2004). The impact of restaurant table characteristics on meal duration and spending. Cornell Hospitality Quarterly, 45(4), 333-346.

Kline, R. B. (2005). Principles and practices of structural equation modeling. New York, NY: Guilford Press.

Kotler, P. (2000). Marketing management (10th ed.). New Jersey, NJ: Prentice Hall. 
Kozak, M., \& Rimmington, M. (2000). Tourist satisfaction with Mallorca, Spain, as an off-season holiday destination. Journal of Travel Research, 38(3), 260-269.

Li, M. H. (2003). The research on the shopping district people's behavior of refuge in Taipei city within seismic disaster: Taking Di Hua Street, Xi Men Ding, Ding Hao Sogo, and Xin Yi trade area as examples (Masters thesis, Chung Hua University, Taiwan).

Liberty Times. (2013). Xinyi district, department gathered, fashion partied. Retrieved from http://news.ltn.com.tw/news/local/paper/652887

Lin, F. Y., Hsiao, J. C., \& Chung, H. F. (2006). Xinyi commercial center. Taipei City Government, Taipei, Taiwan.

Lin, I. Y. (2004). Evaluating a servicescape: The effect of cognition and emotion. International Journal of Hospitality Management, 23(2), 163-178.

Lugosi, P. (2003). The production and consumption of hospitality space (Doctoral dissertation, University of North London).

Lugosi, P. (2008). Hospitality spaces, hospitable moments: Consumer encounters and affective experiences in commercial settings. Journal of Foodservice, 19(2), 139-149.

Markey, S., Halseth, G., \& Manson, D. (2008). Challenging the inevitability of rural decline: Advancing the policy of place in northern British Columbia. Journal of Rural Studies, 24(4), 409-421.

Marshall, R. (2003). Emerging urbanity: Global urban projects in the Asia Pacific Rim. London: Spon Press.

Miles, S. (2010). Spaces for consumption. London: Sage Publications.

Mitchell, D. J., Kahn, B. E., \& Knasko, S. C. (1995). There's something in the air: Effects of congruent or incongruent ambient odor on consumer decision making. Journal of Consumer Research, 22(2), 229-238.

Mittal, V., Kumar, P., \& Tsiros, M. (1999). Attribute-level performance, satisfaction, and behavioral intentions over time: A consumption-system approach. Journal of Marketing, 63(2), 88-101.

Nelson, L. D., \& Meyvis, T. (2008). Interrupted consumption: Disrupting adaptation to hedonic experiences. Journal of Marketing Research, 45, 654-664.

President International Development Corporation. (2012). Experience sharing for the BOT model of Taipei city hall bus station. Retrieved from http://www.topwin.com.tw/goldenthumb/downloads/01-3.pdf

Pullman, M. E., \& Gross, M. A. (2004). Ability of experience design elements to elicit emotions and loyalty behaviors. Decision Sciences, 35(3), 551-578.

Rakodi, C. (2001). Forget planning, put politics first? Priorities for urban management in developing countries. International Journal of Applied Earth Observation and Geoinformation, 3(3), 209-223.

Rakodi, C. (Ed.). (1997). The urban challenge in Africa: Growth and management of its large cities. Tokyo: United Nations University Press.

Ramanathan, S., \& Williams, P. (2007). Immediate and delayed emotional consequences of indulgence: The moderating influence of personality type on mixed emotions. Journal of Consumer Research, 34(2), 212-223.

Richardson, H. W. (1977). The new urban economics: And alternatives. UK: The City Pub.

Rose, R. L., \& Wood, S. L. (2005). Paradox and the consumption of authenticity through reality television. Journal of Consumer Research, 32(2), 284-296.

Schiffman, H. R. (2001). Sensation and perception (5th ed.). New York, NY: John Wiley \& Sons.

Schmitt, B. H. (2003). Customer experience management: A revolutionary approach to connecting with your customers. Hoboken, NJ: John Wiley \& Sons.

Seiders, K., Voss, G. B., Grewal, D., \& Godfrey, A. L. (2005). Do satisfied customers buy more? Examining moderating influences in a retailing context. Journal of Marketing, 69(4), 26-43.

Siddiqui, M. H., \& Tripathi, S. N. (2011). Application of soft operations research for enhancing the servicescape as a facilitator. VIKALPA, 36(1), 33-49.

Sklair, L. (2005). The transnational capitalist class and contemporary architecture in globalizing cities. International Journal of Urban and Regional Research, 29(3), 485-500.

Spielmann, N., Laroche, M., \& Borges, A. (2012). How service seasons the experience: Measuring hospitality servicescapes? International Journal of Hospitality Management, 31(2), 360-368.

Swyngedouw, E., Moulaert, F., \& Rodriguez, A. (2002). Neoliberal urbanization in Europe: Large-scale urban development projects and the new urban policy. Antipode, 34(3), 542-577.

Taipei City Government. (2001). Second overall review of the Xinyi-Planning District. Taipei, Taiwan. 
Taipei Times. (2013a, December 9). IT month Taipei show draws record crowds. Retrieved from http://www.taipeitimes.com/News/front/archives/2013/12/09/2003578608

Taipei Times. (2013b, December 13). Taipei 101 takes over as "King of the Land". Retrieved from http://www.taipeitimes.com/News/front/archives/2013/12/13/2003578910

Tsai, J. H. (2009). Evaluating the utilization of the diversified spaces in Taipei Xinyi-special district (Masters thesis, Taipei University of Technology, Taiwan).

Turley, L. W., \& Milliman, R. E. (2000). Atmosphere effects on shopping behavior: A review of the experimental evidence. Journal of Business Research, 49(2), 193-211.

Verhoef, P. C., Lemon, K. N., Parasuraman, A., Roggeveen, A., Tsiros, M., \& Schlesinger, L. A. (2009). Customer experience creation: Determinants, dynamics, and management strategies. Journal of Retailing, 85, 31-41.

VOA News. (2014). In Taipei, bikes solve some problems, create new ones. Retrieved from http://m.learningenglish.voanews.com/a/taipei-youbike-dc-capital-bike-share/1847107.html\#

Wakefield, K. L., \& Blodgett, J. G. (1994). The importance of servicescapes in leisure service settings. Journal of Services Marketing, 8(3), 66-76.

Wakefield, K. L., \& Blodgett, J. G. (1996). The effects of the servicescape on customers' behavioral intentions in leisure service settings. Journal of Services Marketing, 10(6), 45-61.

Wakefield, K. L., \& Blodgett, J. G. (1999). Customer response to intangible and tangible service factors. Psychology and Marketing, 16(1), 51-68.

Williams, R., \& Dargel, M. (2004). From servicescape to cyberscape. Marketing Intelligence and Planning, 22(3), 310-320.

Yang, T. J. (2009). A discussion of urban space formation in Hsin-Yi district under urban design control (Masters thesis, National Taiwan University, Taiwan). 